\title{
Assessment of Water Quality and Parameters Leading to Eutrophication in an Urban Water Body
}

\author{
R.V.Dhivya Shree, J.Brema,
}

\begin{abstract}
This study has been carried out to assess surface water quality and the status of eutrophication in the UkkadamPeriyakulam lake which is a part of the Coimbatore Anicut channel system. The lake is fed by the canals of NoyyalRiver, it has a waterspreadarea of 320 acres and a storage capacity of $70 \mathrm{mcft}$. The water samples for assessment were collected during post monsoon period of the year 2018-19. The physiochemical parameters such as $\mathrm{pH}$, Total dissolved solids, dissolved oxygen, electrical conductivity, chlorides, nitrates, sulphates, potassium, calcium, magnesium, sodium, phosphorus, total hardness; bio-chemical oxygen demand, chemical oxygen demand, lead and chromium were quantified. The various parameters are used to understand the spatial distribution. The suitability of water for drinking and irrigation purposes based on the results from Water quality index, Residual Sodium Carbonate Index, Sodium Adsorption is being discussed in this paper.

Keywords - Water quality index, Residual Sodium Carbonate Index, Sodium Adsorption
\end{abstract}

\section{INTRODUCTION}

Urban lakes are designated as small water bodies located in cities; they function as important flood regulation sites. They are usually shallow water bodies with municipal pipe network around them, leading to low self-cleaning capacity. The urban lakes are now polluted with contaminants; due to municipal sewage water and other industrial wastewater discharged into the lake, therefore a treatment unit is to be set at the upstream before discharging water into the lake.

Manikandan et al (2016) have identified from their study that Lake is the main key factor for climatic change worldwide and considered as most flexible ecosystem.Pedro Ivo IsáBarrenha et al. (2017) have concluded that the lakes are facing a variety of problems such as eutrophication and heavy metal pollutions due to anthropogenic activities which are caused by rapid urbanization, which brings risk to water quality and consequently affecting the aquatic life of different riverine ecosystem.

Sathyavathishuklaet al (2018) have indicated the potential factor affecting the quantity and quality of available water resource are anthropogenic and urbanization activities, demographic changes on local, global and regional scale. In the present day, fast growth of human population, intensive development of industrial, agricultural based sectors have resulted in excess discharge of these toxic wastes along with the municipal waste materials into the wetland lakes. This

Revised Manuscript Received on April 12, 2019.

R.V.Dhivya Shree, PG Scholar, Department of Civil Engineering, Karunya Institute of Technology and Sciences,Coimbatore, Tamil Nadu, India.

J.Brema, Professor,Department of Civil Engineering, Karunya Institute of Technology and Sciences, Coimbatore, Tamil Nadu, India. has increased nutrient input level against permissible limit which has accelerated eutrophication.

Manikandan et al (2016) concluded the excessive amount of nitrogen and phosphorus are the main nutrients causing eutrophication and is the most consequences of decreased water quality. In worldwide more than one billion people do not have suitable drinking water, and two to three billions lack access to basic sanitation services and about three to five millions peoples are dying annually from water related diseases. Surface waters (fresh water lakes, rivers, streams) are the essential natural water resources. Due to the toxic nature of heavy metals it is the most common pollutant affecting living organisms throughout the world. Heavy metals are being discharged into the aquatic ecosystems playing a major role in the degradation of wetlands and directly affect biotic inhabitants.

Renato I. S. Alves et al (2017) discussed that monitoring of limnological parameters in aquatic resources is essential to assess the quality of water and identify the parameter excess in amount, ultimately aiming at environmental and public health protection. Furthermore, the analysis of dissolved metals in water is a basic approach to understand the state of pollution in a particular freshwater ecosystem. However, monitoring of metals is not sufficient, because water bodies may be affected by other impacts.

\section{STUDY AREA}

Coimbatore is considered as important industrial city in Tamil Nadu, it has around 28 wetlands in and around which is mostly fed by Noyyalriver and it has been used for irrigation purposes and fish culturing by local farmers. The untreated industrial effluents, agricultural and industrial wastes are dumped in these wetlands which can bring more consequences for the aquatic life.

Ukkadamlake has a water spread area of 1.295 sq. km. and an average depth of 5.82m.Ukkadamlake has the largest water spread area and is used for regular fishing. The lake is fed by Noyyalriver and also receives water from Selvachinthamani lake located in the north upstream andhas an outlet connecting it in Valankulam lake. The lakeis contaminated with effluents from sewage release from the city and was encroached by water hyacinth. In 2010, Coimbatore corporation planned to de-silt the lake and clear the encroachments. The corporation leased external consultants and suggested public private partnership model 
for the development of the lake. In 2013, the de-silting was carried out by the Coimbatore Corporation in association with NGO Siruthuli, Residents Awareness Association of Coimbatore and Vijayalakshmi Charitable Trust. The restoration of the lake was funded partly by the government and partly by private corporations and the activity was carried out with the help of volunteers from public.

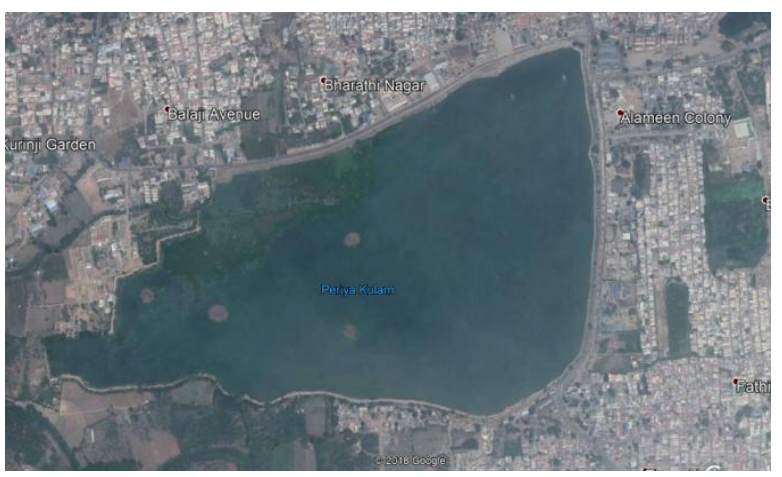

Fig 1.Study area - Ukkadam lake

\section{MATERIALS AND METHODS}

Surface water samples are collected from 14 different points in the lake using boat with the help of local fisherman. The water is kept in the refrigerator to prevent the change of characteristics of water.The samples were analysed for the parameters such as $\mathrm{pH}$, electrical conductivity (EC, $\mu \mathrm{S} / \mathrm{cm})$, total dissolved solids (TDS, ppt), biochemical oxygen demand (BOD, mg/l), chemical oxygen demand (COD, mg/l), chloride (mg/l), phosphate (mg/l), sulphate $(\mathrm{mg} / \mathrm{l})$, sodium $(\mathrm{mg} / \mathrm{l})$, potassium $(\mathrm{mg} / \mathrm{l})$, hardness $(\mathrm{mg} / \mathrm{l})$, dissolved oxygen $(\mathrm{mg} / \mathrm{l})$, turbidity (NPU).

$\mathrm{pH}, \mathrm{EC}$ and TDS were measured using the $\mathrm{pH}$ meter (Model-Digisun-7007), digital conductivity meter (DigisunD1-9009) and Digital TDS meter (Model EI-651-E) equipped with respective electrodes. The Winkler's titrimetric method was used for the determination of dissolved oxygen. BOD was measured by incubating the samples for 5 days at $20^{\circ} \mathrm{C}$. COD was estimated oxidizing the organic matter in the sample by digesting it with potassium dichromate in the presence of strong acid. The unreduced potassium dichromate was then estimated by titrating with ferrous sulphate solution using ferroin as indicator. Sodium and potassium were determined spectrophotometerically. Turbidity was determined using turbidometer.

The water quality index, Kelly's ratio, sodium adsorption ratio, residual sodium carbonate ratio and soluble sodium percentage were calculated using various formula given below.

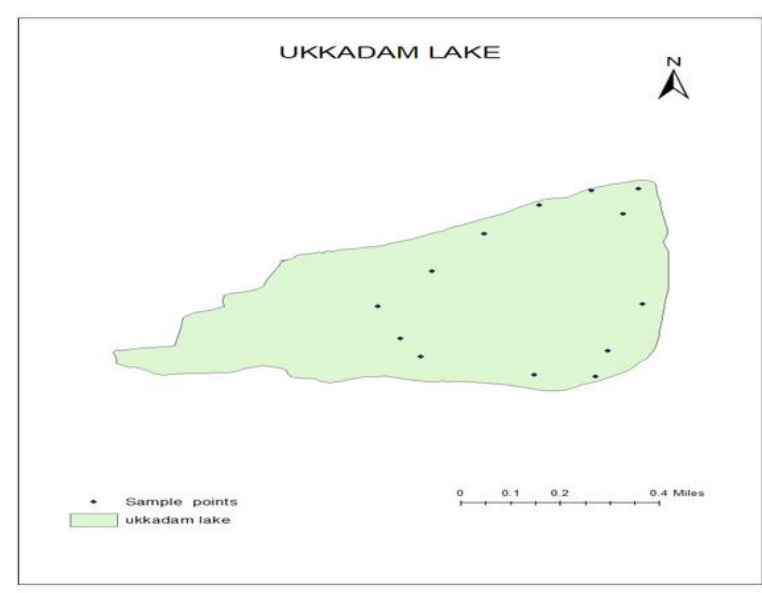

Fig 2. Water collected points

Water Quality index was calculated by using Weighted Arithemetic Mean method

$$
\mathrm{WQI}=£ \mathrm{Q}_{\mathrm{i}} \mathrm{W}_{\mathrm{i}} / £ \mathrm{~W}_{\mathrm{i}}
$$

Quality rating scale Qi of each parameter is calculated by

$$
\mathrm{Q}_{\mathrm{i}}=100\left(\mathrm{~V}_{\mathrm{i}}-\mathrm{V}_{\mathrm{o}} / \mathrm{S}_{\mathrm{i}}-\mathrm{V}_{\mathrm{o}}\right)
$$

Where $\mathrm{V}_{\mathrm{i}}$ - Estimated concentration of ith parameter in the analysed water

$\mathrm{V}_{\mathrm{o}}$ - Ideal value of this parameter in pure water

$\mathrm{S}_{\mathrm{i}}$ - recommended standard value of the ith parameter

Theunit weight(Wi)for each water quality parameter was calculated by

$$
\mathrm{W}_{\mathrm{i}}=\mathrm{k} / \mathrm{S}_{\mathrm{i}}
$$

$\mathrm{K}$ - proportionality constant and can also be calculated by

$$
\mathrm{K}=1 / \text { summation }\left(1 / \mathrm{S}_{\mathrm{i}}\right)
$$

Irrigation sources high in sodium $(\mathrm{Na})$ may lead to the deterioration of soil structure. Water with high sodium causes soil clays and organic matter to disperse or deflocculated. The clays and organic matter clog soil pores, reducing water infiltration and soil aeration. These problems are greater on fine textured soils such as clays and loams than on sandy soils. Calcium $(\mathrm{Ca})$ and magnesium $(\mathrm{Mg})$ cause the soil to flocculate, and therefore counteract the negative effects of $\mathrm{Na}$.

The Sodium Adsorption Ratio (SAR) describes the relationship between soluble $\mathrm{Na}^{+}$and soluble divalent cations $\left(\mathrm{Ca}^{2+}\right.$ and $\left.\mathrm{Mg}^{2+}\right)$. The higher the $\mathrm{Na}$ in relation to $\mathrm{Ca}$ and $\mathrm{Mg}$, the higher the SAR ( Shammi.M et al.2015).

The formula for calculating the sodium adsorption ratio (SAR) is:

$$
\mathrm{SAR}=\frac{\mathrm{Na}^{+}}{\sqrt{\frac{1}{2}\left(\mathrm{Ca}^{2+}+M \mathrm{~g}^{2+}\right)}}
$$

Kelly's ratio is also an important index for irrigation water quality, which is measured considering sodium ion concentration against calcium and magnesium ion concentrations. 
Water with a value of $\mathrm{KR}<1$ is considered suitable for irrigation, while those with a ratio more than 3 are considered as unsuitable for irrigation.

The Kelly's Ratio was calculated using the equation (Kelly, 1963) as:

$$
\text { kelly ratio }=\frac{N a}{C a+M g}
$$

The residual sodium carbonate (RSC) index of irrigation water was used to indicate the alkalinity hazard for soil. RSC should not be higher than 1 and preferably less than +0.5 for considering the water use for irrigation.

$$
\mathrm{RSC} \text { index }=\left[\mathrm{HCO}_{3}{ }^{+}+\mathrm{CO}_{3}^{+}\right]-\left[\mathrm{Ca}^{2+}+\mathrm{Mg}^{2+}\right]
$$

Soluble Sodium Percentage (SSP) was also used to evaluate sodium hazard. Water with a SSP greater than $60 \%$ may result in sodium accumulations causes a breakdown in the soil's physical properties. SSP was calculated by the following equation:

$$
S S P=\frac{N a+K}{C a+M g+N a+K}
$$

\section{RESULTS AND DISCUSSION}

The variations in the physicochemical parameters of the surface water samples collected from different points in the lake are summarized in the table. These parameters were compared with IS 10500 to check the suitability of water for drinking purpose. The average $\mathrm{pH}$ values in various points were observed to be 9.2 which is alkaline in nature and was more than the acceptable limit. The average obtained total dissolved solids value was $726 \mathrm{mg} / \mathrm{l}$ and this exceeds the acceptable limit of $500 \mathrm{mg} / \mathrm{l}$. The alkalinity value was found to be $600 \mathrm{mg} / \mathrm{l}$ and it exceeds the permissible limit $200 \mathrm{mg} / 1$.

The average calcium and magnesium values obtained were $16.2 \mathrm{mg} / \mathrm{l}$ and $42 \mathrm{mg} / \mathrm{l}$ respectively. The calcium and magnesium have a acceptable limit of $75 \mathrm{mg} / \mathrm{l}$ and $30 \mathrm{mg} / \mathrm{l}$ respectively. It was found that calcium was within the acceptable limit and magnesium was greater than acceptable limit and within the permissible limit of $100 \mathrm{mg} / \mathrm{l}$.

Dissolved Oxygen (DO) is mainly involved in maintaining the oxygen balance of aquatic ecosystems based on the tropical and pollution levels. DO acts as a good indicator of healthy status of freshwater systems and the value above $5 \mathrm{mg} / \mathrm{L}$ is a support for all the living organisms. However, this value was less than $3 \mathrm{mg} / \mathrm{L}$ it will cause health risk to human. The DO values of the samples varied between $4-5 \mathrm{mg} / \mathrm{l}$. The present DO results may be attributed due to the temperature changes as well as increased anthropogenic activities in and around these lakes during the period of study.

BOD values ranged between 20.6 - $50.0 \mathrm{mg} / \mathrm{L}$ and the values are above the tolerance level in the lake.COD values varied between $200-400 \mathrm{mg} / \mathrm{l}$ which is in increased concentration. The increased level of BOD and COD shows that there is an increased concentration of organic and inorganic wastes being released into these lakes. Heavy metals such as cadmium, chromium, lead, nickel, iron, copper has been tested, the results showed that cadmium was present in low amount of $0.015 \mathrm{mg} / \mathrm{l}$ and it was found to be within the recommended limit of about $0.003 \mathrm{mg} / 1$.

The water quality index was calculated using weighted arithmetic mean method. The water quality index ranging between 0-25 was excellent, 26-50 was good, 51-75 was poor, 76-100 was very poor and greater than 100 was unfit for drinking purpose. The water quality index of ukkadam was calculated to be 150 to 200 and it is found that the water is unfit for drinking purpose.

Sodium Adsorption ratio values were obtained from the above formula. For the SAR values less than 3 there was no restriction, whereas the soil with SAR value 3-9were saidto betestedand water with values greater than 9 indicate severe damage for soil. The SAR value for Ukkadam Lake is calculated to be 13.2 which is more than 9 which can cause severe damage to the soil. Sodium and potassium ions facilitate the dispersion of clay particles while calcium and magnesium promote their flocculation. The SAR values should be within limit it may affect the behaviour of clay aggregates influences the soil structure and affects the permeability of the soil whose directly depends the water infiltration rate.

Residual sodium carbonate index was calculated using the formula, the values should not be higher than 1 and preferably less than +0.5 for considering the water use for irrigation. The RSC values obtained for Ukkadam lake is 1.5 which is greater than limit and is not suitable for irrigation purpose. The RSC value higher in water causes dispersion of clay soil and affects its infiltration capacity.

Soluble sodium percentage was calculated using formula which was used to find the sodium hazard to the soil. The SSP values less than $60 \%$ indicates good quality of water,suitable for irrigation greater than $60 \%$ represents bad quality i.e., not suitable for irrigation. The SSP value for ukkadamwater is $80 \%$ which is greater than $60 \%$ and it is concluded that the water is not suitable for irrigation purposes.

Kelly's ratio is also an important parameter for irrigation water quality, which is measured considering sodium ion concentration against calcium and magnesium ion concentrations.Water with a value of KR less than 1 is considered suitable for irrigation, while that with a ratio more than 3 is considered as unsuitable for irrigation. The kelly ratio for Ukkadam lake is calculated to be 4 which is greater than 3 and is unsuitable for irrigation.

The SPSS analysis was performed for the irrigation indexes such as SSP, RSC, KR, and SAR. The results showed that KR and SSP are correlated with SAR and RSC. SAR and SSP are correlated with KR. SAR and KR are correlated with SSP. From the above analyze results all indexes are correlated to each other. This shows the water cannot be used for irrigation purpose. 


\begin{tabular}{|l|l|l|l|l|l|l|l|l|l|l|l|l|l|l|}
\hline Parameter & $\mathbf{1}$ & $\mathbf{2}$ & $\mathbf{3}$ & $\mathbf{4}$ & $\mathbf{5}$ & $\mathbf{6}$ & $\mathbf{7}$ & $\mathbf{8}$ & $\mathbf{9}$ & $\mathbf{1 0}$ & $\mathbf{1 1}$ & $\mathbf{1 2}$ & $\mathbf{1 3}$ & $\mathbf{1 4}$ \\
\hline $\mathbf{p h}$ & 9.284 & 9.258 & 9.394 & 9.41 & 9.336 & 9.285 & 9.167 & 9.308 & 9.146 & 9.021 & 8.605 & 9.071 & 9.138 & 8.968 \\
\hline Conductivity( $\boldsymbol{\mu S})$ & 1.187 & 1.107 & 1.145 & 1.186 & 1.188 & 1.228 & 1.555 & 1.500 & 1.465 & 1.289 & 1.623 & 1.158 & 1.224 & 1.226 \\
\hline TDS(mg/l) & 614.1 & 321.9 & 594.2 & 617.8 & 629.2 & 629.4 & 799.5 & 766.6 & 762.6 & 673.3 & 862.4 & 606.9 & 617.7 & 686.3 \\
\hline DO(mg/l) & 5.2 & 5.5 & 5.3 & 6.2 & 5.0 & 5.4 & 6.5 & 5.2 & 6.7 & 5.4 & 6.6 & 5.9 & 5.8 & 5.3 \\
\hline BOD(mg/l) & 32 & 24 & 36 & 25 & 42 & 47 & 29 & 34 & 38 & 48 & 40 & 29 & 31 & 45 \\
\hline COD(mg/l) & 242 & 268 & 470 & 458 & 320 & 378 & 408 & 259 & 456 & 487 & 463 & 396 & 389 & 472 \\
\hline Chloride(mg/l) & 576.8 & 741.0 & 887.5 & 541.3 & 590.1 & 479.2 & 876.2 & 870.6 & 739.6 & 739.6 & 788.4 & 879.5 & 788.4 & 898.4 \\
\hline Sodium(mg/l) & 416.7 & 357.2 & 456.3 & 309.6 & 392.5 & 300 & 389.6 & 304.6 & 371.4 & 407.3 & 392.4 & 346 & 425.8 & 326.4 \\
\hline Potassium(mg/l) & 26.7 & 18 & 35.4 & 35 & 44.8 & 31.8 & 19.9 & 18 & 18.5 & 42.5 & 18.2 & 10.7 & 25.2 & 10.7 \\
\hline Calcium(mg/l) & 17.8 & 11.05 & 18.06 & 18.06 & 12.05 & 13.56 & 13.96 & 14.66 & 15 & 15.55 & 16.7 & 18.8 & 18.5 & 18 \\
\hline Magnesium(mg/l) & 40.73 & 34.8 & 47.13 & 39.84 & 39.19 & 36.18 & 47.13 & 47.2 & 45 & 32.7 & 34.89 & 34.7 & 42.5 & 40 \\
\hline Carbonate(mg/l) & 43 & 45 & 42 & 48 & 40 & 41 & 44 & 45 & 48 & 46 & 47 & 43 & 44 & 49 \\
\hline Bicarbonate(mg/l) & 248 & 266 & 289 & 256 & 189 & 254 & 200 & 298 & 300 & 258 & 245 & 234 & 254 & 298 \\
\hline Sulphate(mg/l) & 83.18 & 76.53 & 62.15 & 81.16 & 102.4 & 1.105 & 82.52 & 97.78 & 87.6 & 96.5 & 91.14 & 69.3 & 108.4 & 83.15 \\
\hline Turbidity(NTU) & 12.5 & 12.8 & 11.2 & 12.3 & 11.7 & 11.25 & 10.5 & 12.4 & 11.5 & 10.11 & 11.23 & 12.84 & 12.42 & 10.97 \\
\hline Alkalinity(mg/l) & 570 & 490 & 620 & 510 & 562 & 450 & 690 & 652 & 548 & 569 & 573 & 654 & 687 & 554 \\
\hline
\end{tabular}

Table 1 - Analysis of Water Samples

\section{CONCLUSIONS}

The present study of Ukkadam Lake showed that the observed values for most of the parameters seemed to be much higher than the recommended level.This may be due to the accumulation of heavy metals, climate change in the recent years, discharge of wastes in folds due to the population growth in and around the Coimbatore city. The water quality index and comparison of obtained values with IS 10500 the water is said to be unfit for drinking purpose. The various index values calculated for irrigation use are found to be greater than the standard limit. An urgent wetland phytoremediation system could be adopted to clean the pollutants to prevent eutrophication and save aquatic life. Further, the effluent water can be treated properly before discharging into the lake. Proper treatment system must be available before discharging.

\section{REFERENCES}

1. Renato I. S. Alves, Carolina S. Machado, Cassio F. Beda, Water Quality Assessment of the Pardo River Basin, Brazil: A Multivariate Approach Using Limnological Parameters, Metal Concentrations and Indicator Bacteria, Archives of Environmental Contamination and Toxicology (2018)

2. Pedro Ivo IsáBarrenha, Marcel Okamoto Tanaka, Frederico Yuri Hanai, Multivariate analyses of the effect of an urban wastewater treatment plant on spatial and temporal variation of water quality and nutrient distribution of a tropical mid-order river, Environ Monit Assess (2018) 190:43

3. Bhuyan, M.S., Bakar, M.A., Sharif, A.S.M., Hasan, M., Water Quality Assessment Using Water Quality Indicators and Multivariate Analyses of the Old Brahmaputra River, Pollution, 4(3): 481-493, Summer 2018

4. Satyavati Shukla • Shirishkumar Gedam - M. V. Khire, Implications of demographic changes and land transformations on surface water quality of rural and urban subbasins of Upper Bhima River basin, Maharashtra, India, Environ Dev Sustain 2018

5. Ismaiel Asad Ismaiel . Graham Bird . Morag A. McDonald, Establishment of background water quality conditions in the Great Zab River catchment: influence of geogenic and anthropogenic controls on developing a baseline for water quality assessment and resource management, Environmental Earth Sciences (2018) 77:50

6. Manikandan R.,Ezhili N., Assessment of Physicochemical Characteristics and the Level of Nutrient Contents as Well as Heavy Metal Ions in Waters of Three Lakes at Coimbatore, Tamil Nadu, India, J. Mater. Environ. Sci. 7 (7) (2016) 2259-2266

7. Adams Sadick, Prince Charles Asante, Correlation analysis of Irrigation water quality parameters from Lake Bosomtwe in the Ashanti Region of Ghana, SCIREA Journal of Agriculture, Volume 2, Issue 2, April 2017

8. Shammi, M., Karmakar, B, Assessment of Salinity Hazard of Irrigation Water Quality in Monsoon Season of BatiaghataUpazila, Khulna District, Bangladesh and Adaption Strategies, Pollution, 2(2): 183-197 , Spring 2016 